\title{
Cooperative role of c-MYC and E6/E7 from two molecular variants of human papillomavirus type 16 upon proliferation and in vitro transformation of primary human keratinocytes
}

\author{
Papel cooperativo de c-MYC e E6/E7 de duas variantes moleculares do \\ Papilomavírus Humano tipo 16 na proliferação e transformação \\ in vitro de queratinócitos humanos primários
}

Jimena Hochmann ${ }^{1}$, Silvaneide Ferreira ${ }^{2}$, João S. Sobrinho ${ }^{2}$, Laura Sichero²

\begin{abstract}
Hochmann J, Ferreira S, Sobrinho JS, Sichero L. Cooperative role of c-MYC and E6/E7 from two molecular variants of human papillomavirus type 16 upon proliferation and in vitro transformation of primary human keratinocytes / Papel cooperativo de c-MYC e E6/E7 de duas variantes moleculares do Papilomavírus Humano tipo 16 na proliferação e transformação in vitro de queratinócitos humanos primários. Rev Med (São Paulo). 2019 Jan-Feb;98(1):52-8.
\end{abstract}

RESUMO: As funções das oncoproteínas E6 e E7 do Papilomavírus Humano tipo 16 (HPV-16) na progressão de células epiteliais imortalizadas para tumores invasivos não são totalmente compreendidas. Aqui, estabelecemos uma nova ligação entre E6 e E7 de duas variantes moleculares de HPV-16 (AA e E-350G) e c-MYC, em relação à cooperação na promoção da transformação maligna de queratinócitos humano primários de prepúcio de recém-nascido (PHK). Nosso objetivo foi estudar os efeitos sinérgicos de E6/E7 e c-MYC na proliferação e no potencial de transformação in vitro de PHKs. Avaliou-se a proliferação celular através da expressão proteica do Antígeno Nuclear de Células Proliferantes (PCNA). Também avaliamos a capacidade de transformação, in vitro, dos PHKs através de dois ensaios complementares. Observamos que E-350G-c-MYC PHKs exibiram um aumento discreto na expressão de PCNA e formaram significativamente mais colônias tanto nos ensaios de soft-ágar quanto nos ensaios em placas de cultura de baixa adesão. No geral, concluímos que a variante E-350G co-transfectada com c-MYC pode promover a transformação celular maligna com eficiência maior do que a variante AA-c-MYC. As propriedades oncogênicas exibidas pela variante E-350G permitem entender em maior detalhe os mecanismos que podem levar à neoplasia cervical humana, dada a maior frequência de sua ocorrência na progressão de lesões precursoras de alto grau para carcinomas invasivos.

Descritores: Papillomavirus humano 16; Transformação celular viral; Genes myc; Queratinócitos; Proteínas oncogênicas.
ABSTRACT: The roles of E6 and E7 oncoproteins of Human Papillomavirus type 16 (HPV-16) in the progression of immortalized epithelial cells to invasive tumors are not fully understood. Here, we establish a novel link between E6 and E7 of two molecular variants of HPV-16 (AA and E-350G), and $\mathrm{c}-\mathrm{MYC}$, regarding the cooperation in promoting malignant transformation of primary human foreskin keratinocytes (PHK). We aimed to study the synergistic effects of E6/E7 and c-MYC upon proliferation, and the in vitro transformation potential of PHK. We evaluated cellular proliferation through the expression of the Proliferating Cell Nuclear Antigen (PCNA) protein and colony formation abilities using soft agar and low attachment plates. We observed that E-350G-c-MYC PHKs exhibited discrete higher PCNA levels and formed significantly more colonies in both soft-agar and when growth in low-adhesion culture plates. Overall, we concluded that the E-350G variant co-transfected with c-MYC might promote malignant cellular transformation with a better efficiency than the AA-c-MYC counterpart. The enhanced oncogenic properties exhibited by the E-350G-c-MYC variant offer insights into mechanisms that may operate in human cervical neoplasia, given the higher frequency of its occurrence in the progression of high-grade precursor lesions to invasive carcinomas.

Keywords: Human papillomavirus 16; Cellular transformation, viral; Genes, myc; Keratinocytes; Oncogene proteins.

1. Virology Section, Facultad de Ciencias, UDELAR, Montevideo, Uruguay. ORCID: https://orcid.org/0000-0002-0875-2333. Email: jhochmann@fcien.edu.uy.

2. Center for Translational Research in Oncology, Instituto do Cancer do Estado de São Paulo, Hospital das Clínicas da Faculdade de Medicina da Universidade de São Paulo, Brazil. ORCID: Sichero L - https://orcid.org/0000-0002-7999-5818. Email: silvaneide. ferreira@hc.fm.usp.br; simao_j@yahoo.com.br; laura.sichero@hc.fm.usp.br.

Corresponding author: Jimena Hochmann, PhD. E-mail: jhochmann@fcien.edu.uy. 


\section{INTRODUCTION}

Tigh-risk Human Papillomavirus $(16,18,31$, $33,35,39,45,51,52,56,58,59$ y 68$)$ are the main etiological agent of cervical cancer. HPV-16 is the most prevalent type and is responsible for about 500,000 new cancer cases and over 250,000 cancer deaths worldwide every year. HPV variants arise in consequence of cumulative nucleotide mutations in key positions of the viral genome and differ in nucleotide sequence by no more than $2 \%$ in coding regions and until $5 \%$ in the noncoding region ${ }^{1}$. Data obtained from $301 \mathrm{HPV}-16$ positive cervical samples from 25 different geographical regions in the world revealed that HPV-16 has evolved along five major branches, two being present mainly in Africa, one Asian-American, one Asian and one in Europe ${ }^{2,3}$. The E6/E7 oncogenes of high-risk HPVs are both necessary and sufficient to immortalize Primary Human Foreskin Keratinocytes (PHKs), and their expression is required for the continued proliferation of HPV-positive cervical cancer cells $\mathrm{s}^{4,5}$. However, these immortalized cells are not tumorigenic in mice, which means that addition. Cellular events are required for the complete transformation of human epithelial cells. Several observations suggest that cooperative signaling of host cellular factors, along with E6 and $\mathrm{E} 7$, are essential in promoting entire tumor progression in vivo ${ }^{6}$.

One of the most studied human oncogenes is $R A S$ which expression leads the immortalized human epithelial cells to a fully transformed phenotype with all the hallmarks of cancerous cells ${ }^{7,8}$. It has also been shown that c-MYC can replace Notch1 in cooperating with HPV-16 E6 and E7 in the transformation of human epithelial cells since c-MYC is a direct t.arget of CBF1-dependent signaling triggered by activated Notch 19 .

Although exacerbated levels of c-MYC are observed in many cases of cervical cancer, the function of c-MYC in the process of HPV-mediated transformation is unclear. E6 is believed to directly transactivate the c-MYC promoter in H358 (bronchio.alveolar carcinoma/non-small cell lung cancer) and $\mathrm{C} 33 \mathrm{a}$ (cervical cancer HPV negative) cells ${ }^{10}$. On contrast, other reports suggest that E6 controls the degradation of c-MYC in a neuroblastoma cell line that expresses high levels of the human N-MYC protein ${ }^{11}$. In addition, it was observed that c-MYC associates with the HPV-16 E6 protein in vivo to transactivate the hTERT promoter in $\mathrm{PHKs}^{12}$. As seen, the mechanisms through E6 leads to transformation can be cell-type specific.

c-MYC belongs to the myc family of genes (MYC, MYCN, MYCL), is located on chromosome 8q24.1, has three exons and encodes a nuclear protein of $62 \mathrm{kDa}$ that holds transcription factor activity and responds to different cell signaling pathways which are responsive to cellular growth factors ${ }^{13}$. The c-MYC gene is frequently activated in human cancers through several mechanisms, such as mutations ${ }^{14,15,16}$, or even, as a result of the inactivation of key controllers of the cell cycle, such as $\mathrm{p} 53^{13}$.

In this study, we analyzed the putative function of c-MYC in HPV-mediated transformation of PHKs as an important partner of E6 and E7 proteins of two molecular variants of HPV-16: Asian-American (AA) and European with the $350 \mathrm{G}$ substitution (E-350G). Here we demonstrated that cells co-transduced with E-350G and c-MYC presented an enhanced in vitro transformation potential in comparison to AA and c-MYC co-expressing cells.

\section{MATERIAL AND METHODS}

\section{Transduction of c-MYC in primary human keratinocytes (PHK), co-transduced or not with E6/E7 of two HPV-16 molecular variants (AA and E-350G)}

Pools of primary newborn foreskin human keratinocytes (PHK) were purchased from Clonetics, NJ, USA (cat n. 00192906, lot n. 0000252415, certificate of analysis provided by the supplier), and maintained in keratinocyte serum-free medium (KSFM) supplemented with $5 \mathrm{ng} / \mathrm{mL}$ epidermal growth factor (EGF) and $50 \mu \mathrm{g}$ / $\mathrm{mL}$ bovine p.ituitary extract (BPE) (Invitrogen, CA, USA). PHKs immortalized by E6 and E7 from different molecular variants of HPV-16 were obtained as previously described $^{17,18}$. HPV-immortalized cells used in this study were tested internally for HPV DNA status, viral RNA expression patterns, and E6/E7 protein expression levels. HPV transduced cells were continuously sub-cultured 1:6 when $80-90 \%$ confluence was reached and considered immortalized after 30 passages $^{19}$. PHKs immortalized with two distinct HPV-16 variants were used throughout this study: E-350G (E6:L83V), and AA (E6:Q14H/H78Y/ L83AA). We infected primary and high passage (>p100) E6/ E7 PHKs w.ith the lentiviral pCDH-puro-c-MYC plasmid (Addgene \# 46970). Briefly, 10 $\mu \mathrm{g}$ of this plasmid was co-transfected with three plasmids encoding the lentiviral proteins Gag, Pol, Env in HEK293T cells using a calcium phosphate protocol. Infectious particles were used to infect HPV-immortalized and normal PHKs using a MOI of 5 in presence of $8 \mu \mathrm{g} / \mathrm{mL}$ of polybrene.

\section{Proliferation assay}

Cell lines (PHK, AA, AA-c-MYC, E-350G, and E-350G-c-MYC) were harvested by trypsin digestion and seeded into 6 -well cell culture plates $\left(1 \times 10^{4}\right.$ cells/well $)$ at day 0 . Cells were dissociated from wells with $0.25 \%$ trypsin and counted every other day manually using a hemocytometer under a microscope. Cell growth curves were obtained from live cell numbers during six days.

\section{Clonogenic assay}

Primary cells, PHKs transducing c-MYC, or PHKs co-transducing E6/E7 of two variants of HPV-16 and 
c-MYC (E-350G-c-MYC and AA-c-MYC) were seeded at low de.nsity (300 cells) in six wells plates. After two weeks with medium changed every other day, cells were stained with $0.01 \%$ crystal violet, and colonies were counted macroscopically. Experiments were performed at least in triplicates three times independently. Colonies were

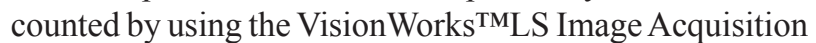
and Analysis software (UVP, Jena, Germany).

\section{Soft agar assay}

One of the hallmarks of transformed cells consists on the ability to grow independent of substrate adhesion. The anchorage-independent condition can be recreated in vitro using a semi-solid medium. For this assay, 7,000 cells were mixed with $0.3 \%$ low melting point (LMP) agarose in KSFM medium and seeded in 24 wells plates on top of a 1\% LMP agarose bed. After 20 days, colonies were stained using $1 \mathrm{mg} / \mathrm{mL}$ MTT (Sigma, MI, USA), and observed macroscopically to visualize the number and size of the colonies formed. Experiments were conducted three times in six replicates.

\section{Immunoblot}

Cells pellets were washed with ice-cold phosphatebuffered saline (PBS), centrifuged, and protein lysates extracted by incubation on ice for $30 \mathrm{~min}$ with RIPA buffer (20 mM Tris- $\mathrm{HCl}, \mathrm{pH}=7.5,150 \mathrm{mM} \mathrm{NaCl}, 0.5 \%$ sodium deoxycholate, $1 \%$ NP-40, $0.1 \%$ SDS) containing complete protease and phosphatase inhibitor cocktails (Roche, Basel, Switzerland). Eighty micrograms of protein extracts were loaded onto 10-15\% SDS-polyacrylamide gels, electrophoresed, and transferred to PVDF membranes (GE Healthcare, Buckinghamshire, UK). The primary antibodies were used at the following dilutions: anticMYC (ab69987, 1:250), anti-PCNA (ab29, 1:1000), and anti-tubulin (1:5,000, OT-9026, Sigma, MI, USA). Anti-rabbit or anti-mouse HRP-conjugated secondary antibodies (GE Healthcare Buckinghamshire, UK) were used at a dilution of 1:5000. Proteins were visualized using the ECL Plus Western Blotting detection system (GE Healthcare, Buckinghamshire, UK) in a ImageQuant LAS 4000 equipment (GE Healthcare, Buckinghamshire, UK). Protein levels were quantified using the ImageQuant TL software (GE Healthcare, Buckinghamshire, UK).

\section{Low attachment assay}

We seeded 50,000 cells on low attachment six well plates with $5 \mathrm{~mL}$ of KSFM. Every three days $500 \mu \mathrm{L}$ of KSFM were added to each well. After thirteen days, colo. nies were photographed using the EVOS FL Auto Imaging System AMAFD 1000 (Life Technologies, MA, USA), and 25 photos were obtained for each well. Experiments were conducted three times in triplicates.

\section{Statistical analysis}

Mean values and standard deviation (SD) are shown. Whenever appropriate, data was analyzed by unpaired twotailed Student's t-test using GraphPad Prism Version 7, and ANOVA for repeated measures to compare proliferation rates using SPSS v.25 for Windows. Significance level was $5 \%$ for all hypothesis.

\section{RESULTS}

\section{Characterization of PHKs co-transduced with E6/E7 of two HPV-16 variants and c-MYC}

We initially transduced c-MYC in HPV-16 immortalized keratinocytes. As expected, PHKs co-infected with AA-c-MYC or E-350G-c-MYC exhibited higher levels of c-MYC expression relative to PHKs transduced only with E6/E7 of HPV-16 or normal PHKs (Figure 1a,b). However, the increment in cMYC expression was statistically significant solely for PHKs transduced with E-350G-c-MYC.
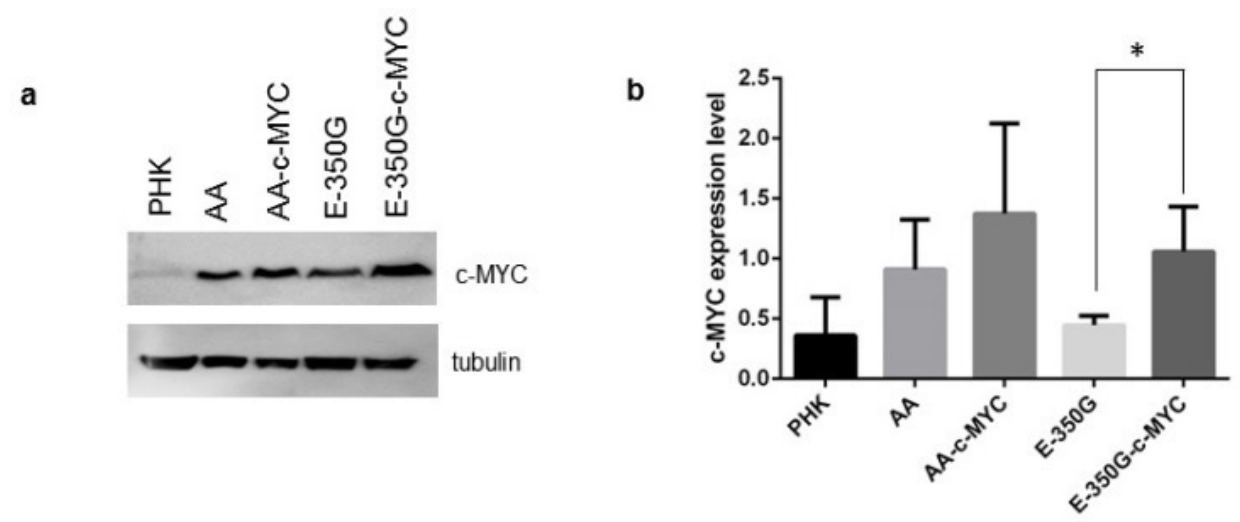

Figure 1. Characterization of PHKs immortalized by E6/E7 of two HPV-16 variants co-transduced with c-MYC. (A) Total protein extracts were submitted to SDS-PAGE followed by immunobloting using antibody against c-MYC. One representative experiment of two independent assays is shown. (B) Densitometric analysis of c-MYC protein expression of parental cells and HPV-16 immortalized PHKs co-transduced not with c-MYC. Values were normalized to tubulin expression levels, and averages \pm SDs from two independent experiments are shown 


\section{E6/E7 HPV-16 immortalized PHKs transduced with c-MYC do not significantly differ in their proliferative potential}

We inquired whether c-MYC increases the proliferation rate of HPV-16 immortalized PHKs. Our results showed that PHKs co-transduced with the E-350G variant and c-MYC presented a discrete but not statistically significant increment in PCNA expression levels relative to that of AA-c-MYC PHKs (Figure 2a,b).Furthermore, we evaluated the growth rate of these cells over a period of 6 days in culture and observed no significant differences among cells immortalized by the different HPV-16 variants and those co-transduced with HPV-16 and c-MYC. Taken together, our data shows that independently of the variant analyzed, HPV-16 immortalized PHKs transduced with c-MYC do not attain differences regarding proliferation. a

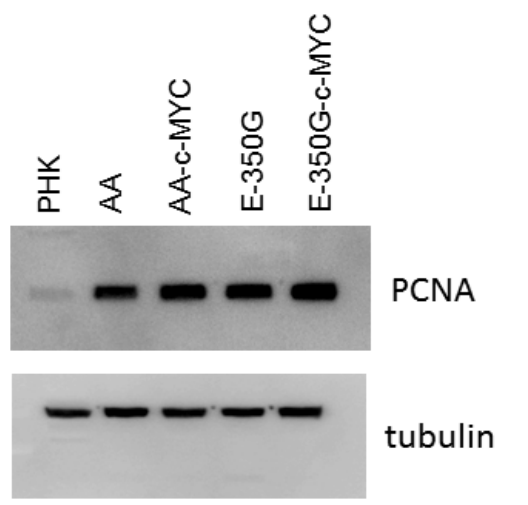

b

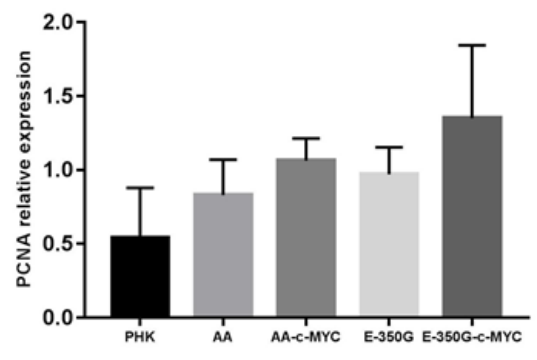

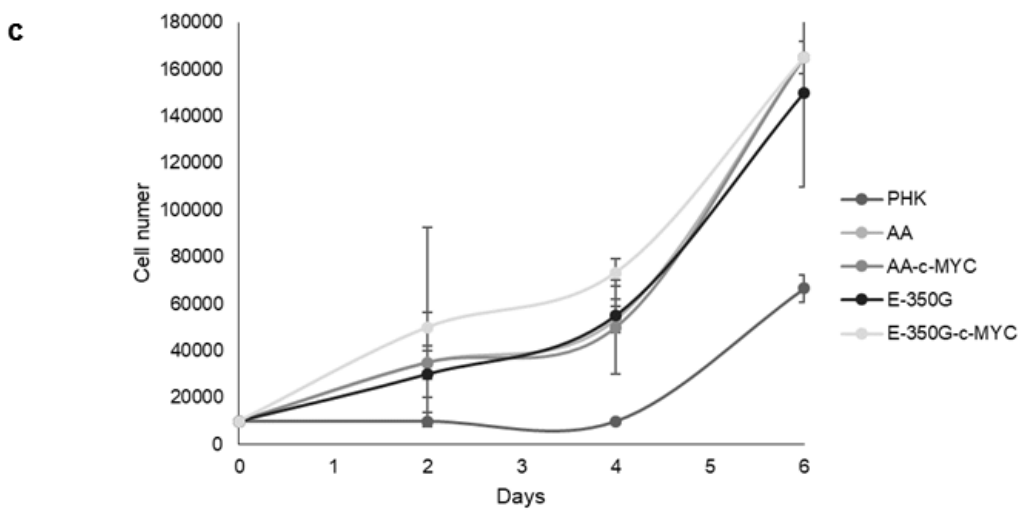

Figure 2. Proliferation ability of PHKs immortalized by E6/E7 of two HPV-16 variants co-transduced with c-MYC. (a) Expression profile of the PCNA protein. Total protein extracts from parental and immortalized PHKs co-transduced or not with c-MYC, were submitted to SDS-PAGE followed by immunoblotting using an antibody against the proliferating cell nuclear antigen (PCNA). One representative experiment of two independent assays is shown. (b) Densitometric analysis of PCNA levels in parental cells and HPV-16 immortalized PHKs co-transduced or not with c-MYC. Values were normalized to tubulin expression levels, and averages \pm SDs of two independent experiments are shown. (c) Cell growth curves over a six days period of normal, and HPV-16 immortalized PHKs transduced or not with c-MYC. Cell numbers were accessed manually with a hemocytometer under a microscope. One representative experiment of two independent assays is shown

Colony formation and transformation potentials of immortalized human keratinocytes co-transduced or not with c-MYC

The cooperative role of c-MYC and E6/E7 from two HPV-16 variants upon in vitro transformation was evaluated using three different approaches: We initially carried out clonogenic assays by plating cells in low density and allowing colonies to grow for two weeks. Our results showed that both variants co-transfected with c-MYC formed significantely more colonies when compared to PHKs. In addition, PHKs co-transduced with the E-350G variant and c-MYC formed even more colonies when compared to PHKs co-transduced with the AA variant and
c-MYC (Figure 3a,b). However, no significant differences were found regarding the colony diameter (Figure $3 \mathrm{c}$ ). Next, cells were plated in semi-solid medium and we observed that PHKs co-transduced with the E-350G variant and c-MYC were also able to produce a significantly higher number of colonies relative to the AA-c-MYC variant counterpart (Figure $4 \mathrm{a}$ and $\mathrm{b}$ ). Finally, our data was further corroborated using an assay that mimics 3D growth conditions, showing a more efficiency in the number of colonies formed by E-350G-c-MYC variant (Figure $4 \mathrm{c}$ and D). In sum, our results point towards a higher in vitro transformation potential for the HPV-16 E-350G variant in cooperation with c-MYC. 
a

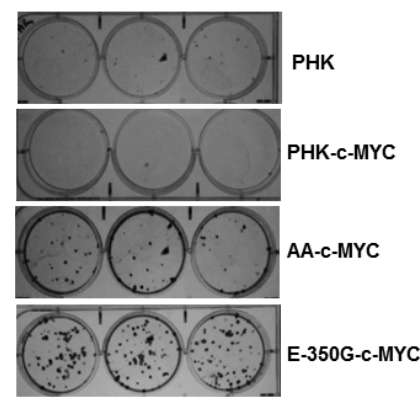

b

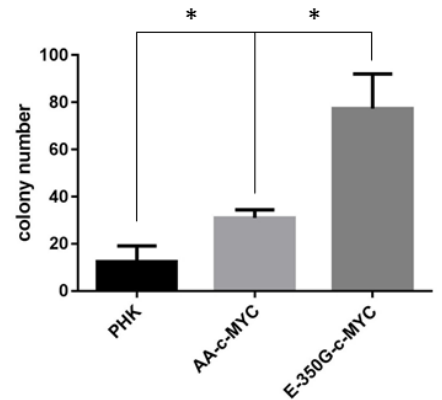

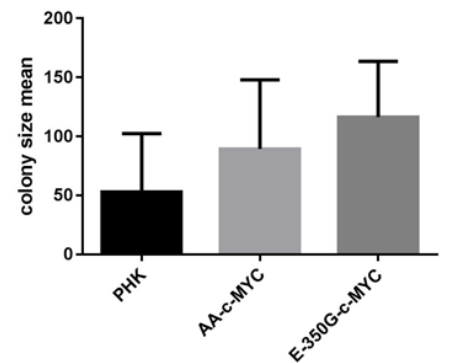

Figure 3. Colony formation potential of HPV-16 immortalized and c-MYC co-transduced cells when plated in low density. (a) For all cultures, 300 cells were seeded in triplicates and grown in six-well plates for 15 days. Colonies formed were visualized by staining with crystal violet and evaluated macroscopically. One representative experiment of three is shown. (b) and (c) Colony number and size were accessed using the the VisionWorks ${ }^{\mathrm{TM}}$ LS Image Acquisition and Analysis software (UVP, Jena, Germany). Averages and \pm SDs from three independent experiments are shown

a
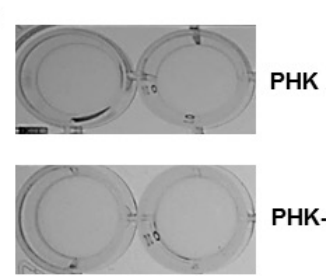

PHK-C-MYC

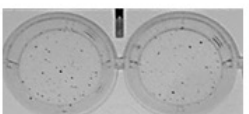

E6-AA-C-MYC

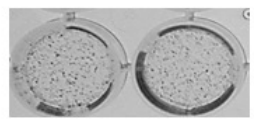

b

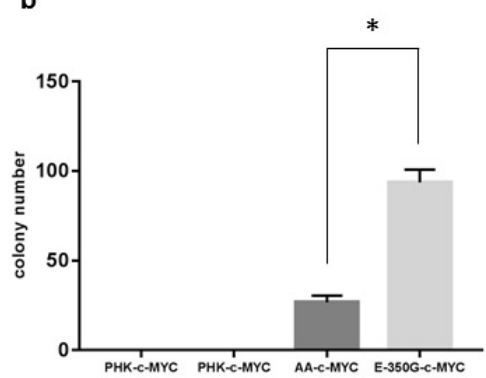

C

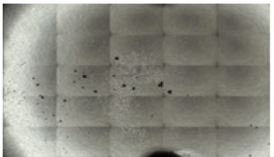

PHK

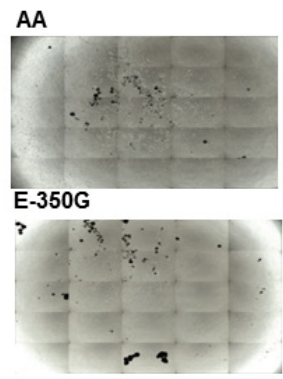

d

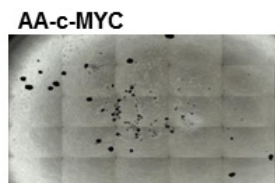

E-350G-C-MYC

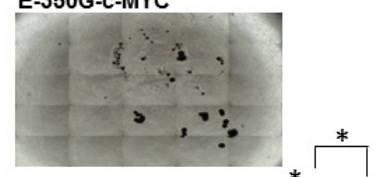

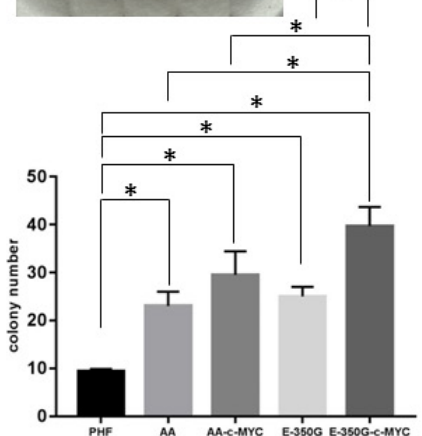

Figure 4. Transformation potential of HPV-16 immortalized and c-MYC co-transduced cells. a) Soft agar assay. After 15 days in culture colonies were stained with MTT and evaluated macroscopically. b) Colony number was accessed for each cell line by counting manually. Averages and \pm SDs from three independent experiments are shown. c) Low attachment assay. After 15 days, 25 photographs were taken from each cell line using the EVOS equipment. d) Colony number was accessed for each cell line by counting manually. Averages and \pm SDs from three independent experiments are shown 


\section{DISCUSSION}

Expression of high-risk HPVs E6 and E7 oncoproteins is necessary for the immortalization of primary keratinocytes, a critical step for oncogenic progression, however insufficient for the complete in vivo transformation of these cells. Thus, the contribution of a host factor would be necessary to achieve a transformed phenotype $^{6}$. It has been previously reported that c-MYC can replace activated Notch 1 in synergizing with HPV-16 E6 and E7 oncoproteins towards cell transformation, once c-MYC expression is regulated by Notch 19 .

In the present study, we evaluated the cooperative role between E6/E7 of two different variants of HPV16 and c-MYC upon PHK proliferation and in vitro transformation using different approaches. Taken together, our data supports a higher transformation potential for the European molecular variant of HPV-16 with a nucleotide substitution in the E6 gene (E-350G) in collaboration with c-MYC in comparison to HPV-16 AA immortalized PHKs further transduced with this cellular gene (AAcMYC-PHK). Our results corroborate a previous study that showed that c-MYC can cooperate with HPV-16 E6 and E7 oncogenes in cell transformation since the introduction of AcN1 or c-MYC in HaCaT(transformed keratinocyte of human skin) cells expressing E6 and E7 resulted in a greater than 4-fold increase in the number of colonies formed on soft agar assays when compared to mock-transfected, or cells expressing solely HPV-16
E6/E7 ${ }^{9}$. Furthermore, Chakrabarti et al. ${ }^{20}$ reported that the E-350G HPV-16 variant enhances MAPK signaling and cooperative transformation with deregulated Notch1, allowing the progression of immortalized human epithelial cells to a complete transformation as accessed using in vitro soft agar assay.

The enhanced oncogenic potential exhibited by the E-350G variant offer insights into mechanisms that may operate in human cervical carcinogenesis. In European populations mostly all HPV-16 molecular variants detected belong to the European branch ${ }^{21,22}$. In Europe, the HPV16 E-350G variant has been shown to associated with an increased risk of viral infection persistence and progression to cervical intraepithelial neoplasia 2 and 3 (CIN2 and 3) and invasive cervical cancer in some populations ${ }^{21,22,23}$. The fact that our data points towards a higher oncogenic 1 attributed to this variant in cooperation with c-MYC, may explain, at least in part, why women infected with the E-350G variant are more prone to develop cervical neoplasias. Nevertheless, it should be highlighted that not all studies conducted in different European populations showed similar results $24,25,26,27,28,29$.

In conclusion, our results indicate that HPV-16 E6/E7 cooperates with c-MYC in promoting in vitro transformation of PHKs. More specifically, we further demonstrated that E-350G-c-MYC PHKs showed the highest oncogenic potential. Nevertheless, further studies are needed to elucidate the molecular mechanisms by which HPV-16 variants differ in their oncogenic potential.

Acknowledgements: We are grateful to FAPESP, and also to Msc Marlous Lana and PhD Daniela Zanatta for their help with retroviral transductions.

Funding: This work was supported by Fundação de Amparo Pesquisa do Estado de São Paulo (FAPESP) [12/16283-9 to L.S., 13/01538-4 to J.H. and 08/57889-1 to L.L.V.], Conselho Nacional de Desenvolvimento Científico e Tecnológico (CNPq) [573799/2008-3 to L.L.V.].

Authors' contributions: Conceived and designed the experiments: JH, JSS, SF, and LS. Performed the experiments: JH, SF, JSS. Analyzed the data: $J H, J S S, S F$, and $L S$. Contributed reagents/materials/analysis tools: $L S$. Wrote the paper: $J H, L S$. All authors read and approved the final manuscript.

Competing Interests: None of the other authors have conflicts of interest to report.

Ethics approval and consent to participate: not applicable

List of abbreviations: Asian-American (AA), cervical intraepithelial neoplasia (CIN), European (E), European 350G(E-350G), human papillomavirus (HPV), Primary Human Foreskin Keratinocytes (PHK), Keratinocyte serum free medium (KSFM), Proliferating Cell Nuclear Antigen protein (PCNA), Activated Notch1 (AcN1), Centromere-binding protein 1(CBF-1), epidermal growth factor (EGF), bovine pituitary extract (BPE), low melting point (LMP), MTT 3-(4,5-dimethylthiazol-2-yl)-2,5-diphenyltetrazolium bromide, phosphate-buffered saline (PBS), Polyvinylidene difluoride (PVDF).

\section{REFERENCES}

1. Bernard HU, Chan SY, Manos MM, Ong CK, Villa LL, Delius H, Peyton CL., Bauer HM, Wheeler CM._Identification and assessment of known and novel human papillomaviruses by polymerase chain reaction amplification, restriction fragment length polymorphisms, nucleotide sequence, and phylogenetic algorithms. J Infect Dis. 1994;170 (5):1077-85.doi: 10.1093/ infdis/170.5.1077.

2. Ho L, Chan S.Y., Burk R.D. Das B.C. Fujinaga K.. Icenogle J.P. Kahn T. Kiviat N. Lancaster W. Mavromara-Nazos P. The genetic drift of human papillomavirus type 16 is a means of reconstructing prehistoric viral spread and the movement of ancient human populations. J. Virol. 1993;67 (11):6413-6423.
3. Ong CK. Chan SY, Campo MS, Fujinaga K, MavromaraNazos P, Labropoulou V, Pfister H, Tay S-K, ter Meulen J, Villa LL, Bernard H. U. Evolution of human papillomavirus type 18: an ancient phylogenetic root in Africa and intratype diversity reflect co-evolution with human ethnic groups. J Virol. 1993;67(11):6424-31.

4. Hawley-Nelson P, Vousden KH, Hubbert NL, Lowy DR, Schiller JT. HPV-16 E6 and E7 proteins cooperate to immortalize human foreskin keratinocytes. EMBO J.1989;8(12):3905-10. doi: 10.1002/j.1460-2075.1989. tb08570.x. 
5. Munger K, Phelps WC, Bubb V, Howley PM,Schlegel R. The E6 and E7 genes of the human papillomavirus type 16 together are necessary and sufficient for transformation of primary human keratinocytes. J Virol. 1989;63(10):4417-21.

6. Moody CA, Laimins LA. Human papillomavirus oncoproteins; pathways to transformation. Nat Rev Cancer. 2010;10(8):550560. doi: 10.1038/nrc2886.

7. Durst M, Gallahan D, Jay G, Rhim JS. Glucocorticoidenhanced neoplastic transformation of human keratinocytes by human papillomavirus type 16 and an activated ras oncogene. Virology. 1989;173 (2):767-771. doi: $10.1016 / 0042-6822(89) 90595$.

8. DiPaoloJ.A, Woodworth CD, Popescu NC, Notario V, Doniger J. Induction of human cervical squamous cell carcinoma by sequential transfection with human papillomavirus 16 DNA and viral Harvey ras. Oncogene. 1989;4 (4):395-9.

9. Subramanyam D. Krishna S. c-Myc substitutes for Notch1CBF1 functions in cooperative transformation with papillomavirus oncogenes. Virology. 2006;347(1):191-8. doi: /10.1016/j.virol.2005.11.028.

10. Kinoshita T, Shirasawa H, Shino Y, Moriya H, Desbarats L, Eilers M, Simizu B. Transactivation of prothymosin alpha and c-myc promoters by human papillomavirus type $16 \mathrm{E} 6$ protein. Virology. 1997;232(1):53-61. doi: /10.1006/viro.1997.8536.

11. Gross-Mesilaty S, et al. Basal and human papillomavirus E6 oncoprotein-induced degradation of Myc proteins by the ubiquitin pathway. Proc Natl Acad Sci U S A. 1998;95(14):8058-63. doi: /10.1073/pnas.95.14.8058.

12. Zhang Y, Dakic A, Chen R, Dai Y, Schlegel R, Liu X. Direct HPV E6/Myc interactions induce histone modifications Pol II phosphorylation and hTERT promoter activation. Oncotarget. 2017;8(56):96323-39. doi: 10.18632/oncotarget.22036.

13. Dang CV. MYC metabolism cell growth and tumorigenesis. Cold Spring Harb Perspect Med. 2013;3(8):pii:a014217. doi: 10.1101/cshperspect.a014217.

13. Dang CV. MYC metabolism cell growth and tumorigenesis. Cold Spring Harb Perspect Med. 2013;3(8). pii:a014217.doi: 10.1101/cshperspect.a014217.

14. Dews M, Homayouni A, Yu D, Murphy D, Sevignani C, Wentzel E, Furth EE, Lee WM, Enders GH, Mendell JT, Thomas-Tikhonenko A. Augmentation of tumor angiogenesis by a Myc-activated microRNA cluster. Nat Genet. 2006;38(9):1060-5. doi: 10.1038/ng1855.

15. Nair SA, Nair MB, Jayaprakash PG, Rajalekshmy TN, Nair MK, Pillai MR. ras and c-myconcoproteins during tumor progression in the uterine cervix. Tumori. 1998;84(5):583-8. doi: $10.1177 / 030089169808400514$.

16. Vita M, Henriksson M. The Myc oncoprotein as a therapeutic target for human cancer. Semin Cancer Biol. 2006;16(4):31830. doi: 10.1016/j.semcancer.2006.07.015.

17. Hochmann J, Simão Sobrinho J, Villa LL, Sichero L. The Asian-American variant of human papillomavirus type 16 exhibits higher activation of MAPK and PI3K/AKT signaling pathways transformation migration and invasion of primary human keratinocytes. Virology. 2016;492:145-54. doi: 10.1016/j.virol.2016.02.015.

18. Sichero L, Sobrinho JS, Villa LL. Oncogenic potential diverge among human papillomavirus type 16 natural variants. Virology. 2012;432(1):127-32. doi: 10.1016/j. virol.2012.06.011.
19. Halbert CL, Demers GW, Galloway DA. The E7 gene of human papillomavirus type 16 is sufficient for immortalization of human epithelial cells. J Virol. 1991;65(1):473-8.

20. Chakrabarti O, Veeraraghavalu K, Tergaonkar V, Liu Y, Androphy EJ, Stanley MA, Krishna S. Human papillomavirus type 16 E6 amino acid 83 variants enhance E6-mediated MAPK signaling and differentially regulate tumorigenesis by notch signaling and oncogenic Ras. J Virol. 2004;78(11):593445. doi: 10.1128/JVI.78.11.5934-5945.2004

21. Londesborough P, Ho L, Terry G, Cuzick J, Wheeler C, Singer A. Human papillomavirus genotype as a predictor of persistence and development of high-grade lesions in women with minor cervical abnormalities. Int J Cancer. 1996;69 (5):364-8. doi:10.1002/(SICI)1097-0215(19961021)69:5<364::AIDIJC2>3.0.CO;2-3

22. Zehbe I, Voglino G, Delius H, Wilander E, Tommasino M. Risk of cervical cancer and geographical variations of human papillomavirus 16 E6 polymorphisms. Lancet. 1998;352(9138):1441-2. doi: 10.1016/S0140-6736(05)612639.

23. Grodzki M, Besson G, Clavel C, Arslan A, Franceschi S, Birembaut P, Tommasino M, Zehbe I. Increased risk for cervical disease progression of French women infected with the human papillomavirus type 16 E6-350G variant. Cancer Epidemiol Biomark Prev. 2006;15 (4):820-2. doi: 10.1158/1055-9965.

24. Zehbe I, Wilander E, Delius H, Tommasino M. Human papillomavirus 16 E6 variants are more prevalent in invasive cervical carcinoma than the prototype. Cancer Res. 1998;58(4):829-33.

25. Bontkes HJ, van Duin M, de Gruijl TD, Duggan-Keen MF, Walboomers JM, Stukart MJ, Verheijen RH, Helmerhorst TJ, Meijer CJ, Scheper RJ, Stevens FR, Dyer PA, Sinnott P, Stern PL. HPV 16 infection and progression of cervical intraepithelial neoplasia: analysis of HLA polymorphism and HPV 16 E6 sequence variants. Int J Cancer. 1998;78(2):16671. doi: 10.1002/(SICI)1097-0215(19981005)78:2<166::AIDIJC8>3.0.CO;2-X.

26. Cornet I, Gheit T, Clifford GM, Combes JD, Dalstein V, Franceschi S, Tommasino M, Clavel C. Human papillomavirus type 16 E6 variants in France and risk of viral persistence. Infect Agent Cancer. 2013;8(1):4. doi: 10.1186/1750-93788-4.

27. Nindl I, Rindfleisch K, Kotz B, Schneider A, Durst M. Uniform distribution of HPV 16 E6 and E7 variants in patients with normal histology cervical intraepithelial neoplasia and cervical cancer. Int J Cancer. 1999;82(2):203-7. doi: 10.1002/(SICI)1097-0215(19990719)82:2<203::AIDIJC9>3.0.CO;2-9.

28. van Duin M, Snijders PJ, Vossen MT, Klaassen E, Voorhorst F, Verheijen RH, Helmerhorst TJ, Meijer CJ, Walboomers JM. Analysis of human papillomavirus type 16 E6 variants in relation to p53 codon 72 polymorphism genotypes in cervical carcinogenesis. J Gen Virol. 2000;81(Pt 2):317-25. doi: 10.1099/0022-1317-81-2-317.

29. Fontecha NA, Basaras MA, Arrese EA, Hernáez SB, Andía DC, Cisterna RAB. Human papillomavirus 16 variants may be identified by E6 gene analysis. Intervirology. 2015;58:143-8. doi: $10.1159 / 000381745$.

Recebido: 13.11 .18

Aceito: 07.03.19 